\title{
IMS President's Report 2015
}

Let me begin by thanking my predecessor Martin Mathieu for his diligent steering of the society as president through 2013-2014.

Changes to the committee for 2015 included the election of Stephen Buckley (Maynooth) as vice-president and the departure of Cora Stack (ITT) after six years service.

At the 2014 AGM, a proposal to establish an Education subCommittee was approved and I am grateful to the members of committee who brought this proposal to fruition in 2015. The subcommittee is chaired by A. O'Farrell (Maynooth). The other current members are C. Mac an Bhaird, C. Stack, A. Ní Shé, E. Oldham, D. Malone, R. Flatley, A. Cronin, C. Lundon, J. Grannell, M. O'Reilly, A. McCluskey, Aoibhinn ní Shúilleabháin and R. Quinlan. The subcommittee will play its part in gathering and representing the views of mathematicians in the Irish education system and in working with other bodies. (For example, the society became a partner of the National Forum for the Enhancement of Teaching and Learning this year.) We wish the members of our education sub-committee well in their work.

Also proposed at the 2014 AGM was a working group to examine the possibility of a new National Committee for Mathematics. This follows dissolution of the RIA Mathematics Committee and its replacement by a combined Physical, Chemical and Mathematical Sciences Committee. Through early 2015, members of the working group teased out some of the issues that might arise in forming a national committee. It became clear that if research and education interests at all levels were to be fairly represented then a national committee could swell to a large number. There would almost inevitably be overlaps both in mission and personnel amongst the new RIA PCMS committee, the IMS committee itself (and the IMS education sub-committee) and the proposed body. Moreover, the necessity of the proposed body is not fully apparent. The idea may be revisited when arguments in favour become stronger.

The current situation for Irish funding of mathematics research, particularly of doctoral students, is a topic of concern to many members. I can report that in 2015 the society was active in presenting these concerns to policy makers and arguing for a fairer deal for the mathematical sciences when funding policy is reviewed. I want 
to thank members S. Gardiner, G. McGuire and vice-president S. Buckley for their active involvement in this area.

For its part, the IMS was able to support the following meetings in 2015:

- Vertex Operator Algebras (NUIG)

- Irish Geometry Conference (MIC)

- SumTop30/GalTop18 (NUIG)

- Annual Irish Workshop on Mathematics Learning (UCD)

- Groups in Galway (NUIG)

The society's own annual meeting was held in UCC as part of the extensive and wonderful celebrations around George Boole's bicentenary. Thanks are due particularly to S. Wills who organised the IMS strand of the conference. Next year is the 40th anniversary of the IMS as our constitution was adopted at a meeting in TCD in April 1976. To celebrate, we return to Trinity college for the annual meeting on April 15-16th. Ironically perhaps, our constitution stipulates the AGM cannot be held before July and so the 2016 AGM will be held later in the year.

A new internet address for the society has been registered: irishmathsoc.org. The website continues to be kindly maintained by R. Timoney and hosted by TCD but we felt it appropriate that the society should have its own domain, independent of any one institution. New on the web page this year, is a roll of past officers of the society. I am also most grateful to Richard for his help with completing the online archival of the Bulletin which was achieved this year. I encourage members, new and old, to rediscover and enjoy those early issues of the IMS Bulletin/Newsletter. Happily, the current issues maintain the standard and so it is appropriate to finish with a thank you to editor Tony O'Farrell, his editorial team, problem page maintainer Ian Short, and Gordon Lessells who continues to quietly oversee printing and distribution of the bulletin.

Michael Mackey, President 21 December 2015 